\title{
OPEN Assessing the evolution of wheat grain traits during the last 166 years using archived samples
}

\author{
Sinda Ben Mariem ${ }^{1}$, Angie L. Gámez ${ }^{1}$, Luis Larraya ${ }^{2}$, Teresa Fuertes-Mendizabal ${ }^{3}$, \\ Nuria Cañameras ${ }^{4}$, José L. Araus ${ }^{5}$, Steve P. McGrath ${ }^{6}$, Malcolm J. Hawkesford ${ }^{7}$, \\ Carmen Gonzalez Murua ${ }^{3}$, Myriam Gaudeul ${ }^{8}$, Leopoldo Medina ${ }^{9}$, Alan Paton ${ }^{10}$, \\ Luigi Cattivelli ${ }^{11}$, Andreas Fangmeier ${ }^{12}$, James Bunce ${ }^{13}$, Sabine Tausz-Posch ${ }^{14}$, \\ Andy J. Macdonald ${ }^{6} \&$ Iker Aranjuelo ${ }^{1 凶}$
}

The current study focuses on yield and nutritional quality changes of wheat grain over the last 166 years. It is based on wheat grain quality analyses carried out on samples collected between 1850 and 2016. Samples were obtained from the Broadbalk Continuous Wheat Experiment (UK) and from herbaria from 16 different countries around the world. Our study showed that, together with an increase in carbohydrate content, an impoverishment of mineral composition and protein content occurred. The imbalance in carbohydrate/protein content was specially marked after the 1960 's, coinciding with strong increases in ambient $\left[\mathrm{CO}_{2}\right]$ and temperature and the introduction of progressively shorter straw varieties. The implications of altered crop physiology are discussed.

Environmental changes, including climate change, land degradation and biodiversity loss, have been particularly apparent in recent decades and are predicted to become even more extreme in the twenty-first century ${ }^{1}$. The environmental conditions in which plants have been growing during the last century have changed considerably since the Industrial Revolution ${ }^{2}$. The atmospheric carbon dioxide concentration $\left[\mathrm{CO}_{2}\right]$ has increased from about $280 \mathrm{ppm}$ in pre-industrial times to $406 \mathrm{ppm}$ reached in $2017^{3}$. A direct consequence of the elevated atmospheric $\left[\mathrm{CO}_{2}\right]$ (and other greenhouse gas concentrations) is the increase in global temperature and evaporative water demand, paralleled by a reduction in water availability in many regions. It is reported that the average global and ocean surface temperature has increased by approximately $0.85^{\circ} \mathrm{C}\left[0.65\right.$ to $1.06^{\circ} \mathrm{C}$ ] over the period 1880 to $2012^{2}$. These changes have affected agriculture globally and will create significant challenges for food security and nutrition in the future. Indeed, as observed by Oury et al. ${ }^{4}$, the beneficial effects expected from the increase in $\left[\mathrm{CO}_{2}\right]$ in European crop production during recent decades have been constrained by the effects of temperature increases and extended drought periods. This is a major issue, because cereal grains are a key source of carbohydrates, proteins, amino acids, lipids, vitamins and minerals, all of which determine the nutritional value and quality of wheat products ${ }^{5}$. More specifically, those crops provide $44 \%$ of the daily dietary intake of $\mathrm{Fe}, 27 \%$ of

\footnotetext{
${ }^{1}$ Spanish National Research Council (CSIC)-Government of Navarre, AgroBiotechnology Institute (IdAB), Av. Pamplona 123, 31006 Mutilva, Spain. 'Institute for Multidisciplinary Applied Biology, Dpto. Agronomía, Biotecnología y Alimentación, Universidad Pública de Navarra, Campus Arrosadia, 31006 Pamplona, Spain. ${ }^{3}$ Department of Plant Biology and Ecology, University of the Basque Country (UPV/EHU), Bilbao, Spain. ${ }^{4}$ Universitat Politècnica de Catalunya, EsteveTerrades 8, Building 4, Castelldefels, Spain. ${ }^{5}$ Integrative Crop Ecophysiology Group, Plant Physiology Section, Faculty of Biology, University of Barcelona, Barcelona, and AGROTECNIO Center, Lleida, Spain. ${ }^{6}$ Sustainable Agriculture Sciences, Rothamsted Research, Harpenden AL5 2JO, Hertfordshire, UK. 'Plant Sciences, Rothamsted Research, Harpenden AL5 2JO, Hertfordshire, UK. ${ }^{8}$ Institut de Systématique, Évolution, Biodiversité (ISYEB), Muséum National D'Histoire Naturelle, CNRS, EPHE, UA, Sorbonne Université, 57 rue Cuvier, CP 39, 75005 Paris, France. ${ }^{9}$ Spanish National Research Council (CSIC), Real Jardín Botánico, C/ Claudio Moyano 1, Madrid, Spain. ${ }^{10}$ Royal Botanic Gardens Kew, Kew Richmond TW9 3AB, UK. ${ }^{11}$ Agricultural Research Council (CREA), Centre for Genomics and Bioinformatics, Via San Protaso 302, Fiorenzuolad'Arda, Italy. ${ }^{12}$ Institute of Landscape and Plant Ecology, University of Hohenheim, August-von-Hartmann-Str. 3, 70599 Stuttgart, Germany. ${ }^{13}$ Adaptive Cropping Systems Lab (Retired), Beltsville Agricultural Research Center, Agricultural Research Service, US Department of Agriculture, Beltsville, MD 20705, USA. ${ }^{14}$ Department of Agriculture, Science and the Environment, School of Health, Medical and Applied Sciences, CQ University Australia, Rockhampton, QLD, Australia. ${ }^{\circledR}$ email: iker.aranjuelo@csic.es
} 
$\mathrm{Mg}$, 25\% of $\mathrm{Zn}$ and $31 \%$ of $\mathrm{Cu}^{6}$. Further, wheat is the second most important food crop after rice, and provides $20 \%$ of the daily protein and food calories worldwide ${ }^{7}$.

Environmental conditions have a significant impact on crop production. Since the current atmospheric $\left[\mathrm{CO}_{2}\right]$ is generally limiting for plants with photosynthetic $\mathrm{C}_{3}$ metabolism, the available information suggests that increases in $\left[\mathrm{CO}_{2}\right]$ should contribute to increased crop growth and yield ${ }^{8,9}$. Alongside changes in crop yield, other studies carried out during the last few decades ${ }^{10,11}$ have revealed that exposure to increasing $\left[\mathrm{CO}_{2}\right]$ causes alterations to the mineral content of plant tissues, total protein concentration and lipid composition. Within this context, it has been suggested that because grains are predominantly composed of carbohydrates (mostly in the form of starch), the expected increases in starch concentrations due to the high $\left[\mathrm{CO}_{2}\right]$ could dilute other nutrients, including proteins, lipids, vitamins, and minerals ${ }^{12,13}$.

Most plant studies are based on experiments in controlled environment (such as growth chambers) or field conditions, in which $\left[\mathrm{CO}_{2}\right]$ concentrations were fixed at 550-700 ppm. According to the different scenarios proposed by the IPCC ${ }^{2}$, these may be the ambient $\left[\mathrm{CO}_{2}\right]$ values that will be reached by 2050 and 2100 , respectively. Nevertheless, new approaches to field studies have been developed. These include free air systems, such as the free air $\left[\mathrm{CO}_{2}\right]$ enrichment (FACE), controlled $\left[\mathrm{CO}_{2}\right]$ greenhouses $(\mathrm{CGH})$, or open-top chambers $(\mathrm{OTC})^{14,15}$. It should be noted that, according to Högy et al. ${ }^{16}$, the high $\left[\mathrm{CO}_{2}\right]$ stimulation effect might be larger in growth chambers and glasshouses compared to field exposure. While FACE overcomes many of the disadvantages associated with chamber and glasshouse experiments, some potential limitations have been attributed to these facilities when simulating natural growth conditions. A number of challenges exist when conducting FACE experiments, including the difficulty of managing large numbers of sites, replication within sites, physiological impact of a relatively abrupt increase in $\left[\mathrm{CO}_{2}\right]$, effect of $\mathrm{CO}_{2}$ influx on breaking up an inversion layer, and consequent impact on temperature fluctuations within the open-top chamber ${ }^{17,18}$. Consequently, while FACE experiments approach natural conditions more closely than open-top chambers or other means of exposing plants to elevated $\left[\mathrm{CO}_{2}\right]$, they may still represent an approximation of natural growing conditions, albeit a method that is close to natural growth conditions. This may be a major issue to consider because the more realistic the experimental conditions, the more likely it is that the resultant predictions will reflect the reality of the future. However, few studies have addressed the effect of lower-than-present $\left[\mathrm{CO}_{2}\right]$ on grain quality and to the best of our knowledge, all of them have been performed in growth chambers simulating past conditions. As an alternative, the analyses of old samples from herbaria and other repositories should allow direct assessment of the effect of past growing conditions on contemporary samples from crops that were grown at that time. Within this context, in the last two decades, several studies have highlighted the use of archived material to analyse the changes in plant mineral composition over recent decades ${ }^{6,19}$. However, herbarium material has often insufficient information about the location and environmental conditions where the plants were grown or the cultivars used.

The data presented in this paper aims to evaluate the impact of long-term changes in atmospheric $\left[\mathrm{CO}_{2}\right]$, temperature and rainfall conditions on wheat grain quality traits (carbohydrates, protein and mineral concentration) in archived samples during the last 166 years and the association between such quality traits and increased yield.

\section{Material and methods}

Grain material collection. In this study, bread and durum wheat grains were collected from archives of 16 countries around the world (Table 1), from 1850 to 2016. All grain samples selected were intact, without any visible signs of degradation. One part of the archived grain samples originated from the Broadbalk Wheat experiment (Rothamsted, UK). They were taken from plots given annual applications of Farmyard Manure ( 35 tha $^{-1}$ fresh material) since 1843. Another part of the samples (called the 'global samples') originated from 16 countries, and were removed from herbarium specimens stored at the Universitat Politecnica de Catalunya (Castel ldefels, Spain), Muséum National d'Histoire naturelle (Paris, France), Real Jardín Botánico (Madrid, Spain) and Royal Botanic Gardens (Kew Richmond, United Kingdom).

The Broadbalk experiment is the oldest continuous agronomic field experiment in the world, which started in 1843. This 176 year-old experiment provides a large number of archived crop and soil samples from a wide range of agricultural, environmental and ecological conditions. Grain yield data (1850-2016) were available for the Broadbalk experiment, but not from the other sites used in this study. Wheat varieties analyzed in the current study are shown in Table S1. In addition, thousand kernel weights (TKW) were available for Broadbalk from 1974 until 2016. In the early years (1844-1901), the crop from each plot was cut by hand with scythes, bound into sheaves and carted into the barns to await threshing. Broadbalk is now harvested by a small plot combine harvester with a $2 \mathrm{~m}$ cut width. Yields of grain and straw are recorded, and samples stored for chemical analyses.

Environmental $\left[\mathrm{CO}_{2}\right]$, temperature and precipitation data between $\mathbf{1 8 5 0}$ and 2016. Global atmospheric $\left[\mathrm{CO}_{2}\right]$ values (Table 2) for the period from 1850 to 2016 were obtained from the European Environment Agency web page ${ }^{3}$. Data corresponding to the evolution of ambient temperature were extracted from the Intergovernmental Panel on Climate Change ${ }^{20}$. Average temperature and precipitation recorded at Rothamsted (Table 2) were provided by the Department of Computational and Analytical Sciences.

Grain quality parameters. Carbon isotope discrimination $\left(\Delta^{13} C\right)$. Carbon isotope composition was determined in milled grain samples. For each sample, $15 \mathrm{mg}$ of finely milled material was weighed and analysed at the research support service of the Universidade da Coruña (Spain) using an elemental analyzer (EA1108; Carlo Erba Strumentazione, Milan, Italia) coupled to an isotope ratio mass spectrometer (Delta C; Finnigan, Mat., Bremen, Germany) operating in continuous flow mode. Values were expressed in composition units as 


\begin{tabular}{|c|c|c|c|c|}
\hline Continent & Country & Location & Sampling year & Number of replicates per year \\
\hline \multirow{22}{*}{ Eurasia } & \multirow{11}{*}{ Spain } & Albacete & 1900 & 3 \\
\hline & & \begin{tabular}{|l|} 
Lleida \\
\end{tabular} & 1900 & 3 \\
\hline & & \begin{tabular}{|l|} 
Logroño \\
\end{tabular} & 1850 & 3 \\
\hline & & Madrid & 1920 & 3 \\
\hline & & \begin{tabular}{|l|} 
Lugo \\
\end{tabular} & 1953 & 3 \\
\hline & & Segovia & 1985 & 3 \\
\hline & & Valladolid & 1985 & 3 \\
\hline & & Serrania de Ronda & 1905 & 3 \\
\hline & & Aranjuez & 2015 & 3 \\
\hline & & Cordoba & 2015 & 3 \\
\hline & & Zamora & 2015 & 3 \\
\hline & \multirow{3}{*}{ United Kingdom } & Rothamsted & {$[1850-2016]$} & 3 \\
\hline & & Regent Road, Leicester & 1944 & 3 \\
\hline & & City of London, Middlesex & 1945 & 3 \\
\hline & \multirow{2}{*}{ New Caledonia } & No data & 1937 & 3 \\
\hline & & Pouembout & 1965 & 3 \\
\hline & \multirow{2}{*}{ Italy } & Tuscany & 1883 & 3 \\
\hline & & Fiorenzuola d'Arda & 2016 & 14 \\
\hline & Serbia/UK & $\begin{array}{l}\text { Suva plains but cultivated at Royal Botanic } \\
\text { Gardens Kew }\end{array}$ & 1923 & 3 \\
\hline & Germany & Hohenheim & 2016 & 3 \\
\hline & Russia & No data & 1900 & 3 \\
\hline & No data (Asia) & No data & 1910 & 3 \\
\hline \multirow{2}{*}{ Africa } & Algeria & Oran & 1856 & 3 \\
\hline & Nigeria & No data & 1921 & 3 \\
\hline South America & Argentina & No data & 1900 & 3 \\
\hline \multirow{2}{*}{ North America } & \multirow{2}{*}{ USA } & No data & 1900 & 3 \\
\hline & & Beltsville & 2016 & 3 \\
\hline \multirow{4}{*}{ Asia (Near East) } & \multirow{2}{*}{ Iraq } & Zakh-Mosul & 1947 & 3 \\
\hline & & Mariye $4 \mathrm{~km} \mathrm{NW}$ of Rawa & 1947 & 3 \\
\hline & Iran & locality illegible & 1885 & 3 \\
\hline & Yemen & Wadi Hadhramant & 1946 & 6 \\
\hline Asia & China & No data & 2016 & 6 \\
\hline Oceania & Australia & No data & 2016 & 8 \\
\hline
\end{tabular}

Table 1. Geographic origin and sampling year of archived wheat grain samples.

$$
\delta^{13} \mathrm{C}(\%)=\left[\left(\mathrm{R}_{\text {sample }} / \mathrm{R}_{\text {standard }}\right)-1\right] \times 1000,
$$

where the ${ }^{13} \mathrm{C} /{ }^{12} \mathrm{C}$ ratio of the sample is noted as $\delta^{13} \mathrm{C}$ and expressed in $\%$, whereas $\mathrm{R}_{\text {standard }}$ is the molar abundance ratio of the secondary standard calibrated against the primary standard Pee Dee Belemnite $\left(\delta^{13} \mathrm{C}\right)$. The $\delta^{13} \mathrm{C}$ values were later transformed into carbon isotopic discrimination values $\left(\Delta^{13} \mathrm{C}\right)$ according to Farquhar et al. ${ }^{21}$ as follows:

$$
\Delta^{13} \mathrm{C}(\% \mathrm{o})=\left(\delta^{13} \mathrm{C}_{\mathrm{air}}(\% \mathrm{o})-\delta^{13} \mathrm{C}_{\mathrm{VPDV}}(\% \mathrm{o})\right) /\left(1+\left(\delta^{13} \mathrm{C}_{\mathrm{VPDV}}(\% \mathrm{o}) / 1000\right)\right)
$$

where $\delta^{13} \mathrm{C}_{\text {air }}(\%)$ is the ratio of the isotopes of ${ }^{13} \mathrm{C}$ and ${ }^{12} \mathrm{C}$ in the air, which varies through time, and $\delta^{13} \mathrm{C}_{\mathrm{VPDV}}$ (\%) refers to carbon isotope discrimination of grain sample. Air $\delta^{13} \mathrm{C}$ values were obtained from Zhao et al. ${ }^{19}$.

Starch and soluble sugars concentrations. Milled grain samples were extracted by the addition of $0.5 \mathrm{~mL}$ of $100 \%$ ethanol then another $0.5 \mathrm{~mL}$ of $80 \%$ ethanol to approximately $25 \mathrm{mg}$ of sample and heated in a thermomixer $\left(70^{\circ} \mathrm{C}, 90 \mathrm{~min}, 1100 \mathrm{rpm}\right)$. The mixture was centrifuged $\left(22^{\circ} \mathrm{C}, 10 \mathrm{~min}, 14,000 \mathrm{rpm}\right)$ and the supernatant was used for the determination of soluble sugars (glucose, fructose and sucrose). The samples were diluted with water $\left(300 \mu \mathrm{L}\right.$ sample $+700 \mu \mathrm{L} \mathrm{H}_{2} \mathrm{O}$ Mili-Q) and measured using an ionic chromatograph (ICS-3000, Thermo Scientific Dionex, USA). Reference was made to sugar standards of known concentrations (50 mM). The pellet was used to determine the starch content. Starch was solubilized by adding $\mathrm{KOH}(0.2 \mathrm{~N})$ to the pellet, and the $\mathrm{pH}$ was adjusted to 4.8 with acetic acid $(0.1 \mathrm{~N})$. The extraction was performed with the kit containing the enzyme amyloglucosidase (R-Biopharm, AG; Darmstadt, Germany) and the absorbance was measured with a spectrophotometer at $340 \mathrm{~nm}$. 


\begin{tabular}{|c|c|c|c|c|c|c|}
\hline \multirow[b]{2}{*}{ Area } & \multicolumn{2}{|c|}{$\left[\mathrm{CO}_{2}\right](\mathrm{ppm})$} & \multicolumn{2}{|c|}{$\begin{array}{l}\text { Temperature } \\
\left({ }^{\circ} \mathrm{C}\right)\end{array}$} & \multicolumn{2}{|c|}{$\begin{array}{l}\text { Precipitation } \\
(\mathbf{m m})\end{array}$} \\
\hline & Years & Values & Years & values & Years & values \\
\hline \multirow{20}{*}{ Global } & 1850 & 286 & 1850 & 13.7 & \multirow{20}{*}{\multicolumn{2}{|c|}{ No data }} \\
\hline & 1856 & 286 & 1860 & 13.6 & & \\
\hline & 1883 & 293 & 1870 & 13.8 & & \\
\hline & 1885 & 293 & 1880 & 13.9 & & \\
\hline & 1900 & 297 & 1890 & 13.7 & & \\
\hline & 1905 & 299 & 1900 & 13.8 & & \\
\hline & 1910 & 299 & 1910 & 13.5 & & \\
\hline & 1921 & 303 & 1920 & 13.7 & & \\
\hline & 1923 & 305 & 1930 & 13.9 & & \\
\hline & 1937 & 308 & 1940 & 14.0 & & \\
\hline & 1947 & 310 & 1950 & 13.8 & & \\
\hline & 1953 & 312 & 1960 & 13.9 & & \\
\hline & 1955 & 314 & 1970 & 13.9 & & \\
\hline & 1965 & 318 & 1980 & 14.0 & & \\
\hline & 1975 & 331 & 1990 & 14.2 & & \\
\hline & 1985 & 345 & 2000 & 14.4 & & \\
\hline & 1990 & 352 & 2010 & 14.7 & & \\
\hline & 2000 & 378 & 2016 & 14.9 & & \\
\hline & 2010 & 390 & & & & \\
\hline & 2016 & 400 & & & & \\
\hline \multirow{8}{*}{ Rothamsted } & 1850 & 286 & 1878 & 9.28 & 1878 & 814.2 \\
\hline & 1900 & 297 & 1900 & 9.37 & 1900 & 715.8 \\
\hline & 1955 & 314 & 1955 & 8.99 & 1955 & 592.1 \\
\hline & 1975 & 331 & 1975 & 9.60 & 1975 & 612.3 \\
\hline & 1990 & 352 & 1990 & 10.25 & 1990 & 597.4 \\
\hline & 2000 & 378 & 2000 & 10.20 & 2000 & 973.5 \\
\hline & 2010 & 390 & 2010 & 9.01 & 2010 & 644.2 \\
\hline & 2016 & 405 & 2016 & 10.35 & 2016 & 679.3 \\
\hline
\end{tabular}

Table 2. Average environmental data recorded from 1850 to 2016.

Protein content. Grain protein content (\%) was determined according to Suchy et al. ${ }^{22}$.

Mineral composition. In each case, $100 \mathrm{mg}$ of pulverized dry grain samples were analysed ${ }^{23}$. C and $\mathrm{N}$ concentrations (\%) were determined using an elemental analyzer (EA1108; Carlo Erba Strumentazione, Milan, Italia). In addition, micro- and macro-nutrients $(\mathrm{Cu}, \mathrm{Zn}, \mathrm{Fe}, \mathrm{Mn}, \mathrm{K}, \mathrm{P}, \mathrm{Mg}, \mathrm{Ca}$ and $\mathrm{Na}$ ) were quantified using ICP/ OES (inductively coupled plasma/optical emission spectrometry, iCAP 6500 Duo, Thermo Fisher Scientific, Waltham, USA).

Data analyses. Given the long time-series considered, wheat samples received from herbaria were harvested from different locations and periods. Distinct genotypes were represented within each sampling year, with different number of repetitions. In view of the available data, the statistical analyses aimed to evaluate the trend of grain quality parameters over 166 years by calculating the average per year, without considering the genotype effect. To study the 'year' effect on the different parameters measured for global and Rothamsted grain samples, a simple analysis of variance (ANOVA) was performed by using STATGRAPHICS Centurion version 17.1.02 program (Bitstream, Cambridge, MN). For analytical variables, a multiple-range test (Fisher's least significant differences, LSD) was applied to test for statistical differences between years. Multifactor analyses of variance and Pearson correlation analyses were performed between the different parameters and the environmental factors $\left(\left[\mathrm{CO}_{2}\right]\right.$, temperature and precipitation) with the R software (RStudio v.3.4.2, 2017; Boston-Seattle, USA). The correlations between variables were considered significant when $p<0.05$.

\section{Results}

Global samples. Environmental conditions. Atmospheric $\left[\mathrm{CO}_{2}\right]$ has been rising since 1850, and results in Table 2 showed that two periods can be distinguished: a first period (1850-1965), during which the average $\left[\mathrm{CO}_{2}\right]$ slowly rose by $31 \mathrm{ppm}$ in 115 years; and a second period (1965-2016) during which a swift increase of $\left[\mathrm{CO}_{2}\right]$ of $82 \mathrm{ppm}$ was recorded over 51 years. Therefore, the analysis of the effect of climate change on global wheat grain quality was based on the comparison among years, and also between these two periods (Table 3). 


\begin{tabular}{|l|c|c|l|}
\hline Grain quality traits & {$[\mathbf{1 8 5 0}-\mathbf{1 9 5 5}]$} & {$[\mathbf{1 9 6 5}-\mathbf{2 0 1 6})$} & $\boldsymbol{p}$ value \\
\hline$\Delta^{13} \mathrm{C}(\%)$ & $16.53 \pm 0.23$ & $16.50 \pm 0.36$ & 0.940 \\
\hline Starch $(\mu \mathrm{mol} / \mathrm{g} \mathrm{DW})$ & $2712.72 \pm 117.48$ & $2900 \pm 33.11$ & 0.344 \\
\hline Sucrose $(\mu \mathrm{mol} / \mathrm{g} \mathrm{DW})$ & $13.83 \pm 2.93$ & $15.19 \pm 3.33$ & 0.794 \\
\hline Glucose $(\mu \mathrm{mol} / \mathrm{g} \mathrm{DW})$ & $1.01 \pm 0.19$ & $1.89 \pm 0.51$ & $\mathbf{0 . 0 2 7}$ \\
\hline Fructose $(\mu \mathrm{mol} / \mathrm{g}$ DW) & $3.14 \pm 0.59$ & $2.92 \pm 0.41$ & 0.821 \\
\hline Protein content $(\%)$ & $16.96 \pm 1.28$ & $13.07 \pm 0.8$ & $\mathbf{0 . 0 4 9}$ \\
\hline Carbon content $(\%)$ & $40.81 \pm 0.33$ & $41.53 \pm 0.4$ & 0.187 \\
\hline $\mathrm{C} / \mathrm{N}(\%)$ & $17.16 \pm 0.56$ & $20.6 \pm 0.84$ & $\mathbf{0 . 0 3 9}$ \\
\hline
\end{tabular}

Table 3. Global averages of wheat grain quality traits in [1850-1955] and [1965-2016]. Mean \pm standard error (SE) $(n=3-18)$. The calculation of $p$ values is based on one-way ANOVA. Values in bold indicate statistical significance $(p<0.05)$.

The global mean annual temperature presented in Table 2 showed that it has increased by $1.2{ }^{\circ} \mathrm{C}$ from 1850 to 2016, with fluctuations recorded in-between.

Carbon isotope discrimination $\left(\Delta^{13} \mathrm{C}\right)$. The results of carbon isotope discrimination calculated from 1850 to 2016 did not show a clear trend during this period (Fig. 2A). While the global carbon isotope discrimination $\left(\Delta^{13} \mathrm{C}\right)$ showed significant differences among years between 1850 and $2016(p<0.001$; Fig. 2A), no significant difference was observed between 1850-1955 and 1965-2016 (16.53\%o vs. 16.50\%o respectively; Table 3). Pearson analyses did not show any significant correlation, neither between $\Delta^{13} \mathrm{C}$ and $\left[\mathrm{CO}_{2}\right]$ nor between $\Delta^{13} \mathrm{C}$ and temperature (Table 5). Similarly, the multifactor analysis of variance (Table 6) indicated that there are no significant effects of $\left[\mathrm{CO}_{2}\right]$ and temperature on carbon isotope discrimination, and only the interaction between these two environmental factors was statistically significant $(p=0.004)$.

Non-structural carbohydrates. Starch content. The comparison of grain starch content among years (Fig. 3A) showed significant differences between years until 1946, but since 1953, the results showed higher values compared to the previous period and stability in starch content was detected. Further, the comparison between the two periods (Table 3) showed a non-significant increase of grain starch content by $7 \%$. Results presented in Table 5 showed non-significant negative correlations between starch content and high temperature $(\mathrm{r}=-0.175)$ whereas significant positive correlation was detected with $\left[\mathrm{CO}_{2}\right](\mathrm{r}=0.247)$. The multifactor analysis of variance presented in Table 6 showed that $\left[\mathrm{CO}_{2}\right]$ and temperature have significant effects on grain starch content, while the interaction $\left[\mathrm{CO}_{2}\right] \times$ temperature has no significant effect $(p=0.525)$.

Soluble sugars concentrations. Sucrose, glucose and fructose concentrations of global samples showed an increasing trend since 1975 (Fig. 4A). The comparison between the two periods (1850-1955 vs. 1965-2016; Table 3) showed non-significant differences for sucrose and fructose, whereas a significant increase was found for glucose $(p=0.027)$. Pearson analyses showed significant positive correlations between $\left[\mathrm{CO}_{2}\right]$ and glucose and sucrose concentrations, and between temperature and glucose and fructose concentrations (Table 5). Table 5 shows that $\left[\mathrm{CO}_{2}\right]$ had a significant effect on increasing glucose and sucrose concentrations, but no effect was recorded on fructose concentration. The interaction $\left[\mathrm{CO}_{2}\right] \times$ temperature only significantly affects sucrose concentration.

Protein content. Protein content has varied among years since 1850 (Fig. 5A), and the comparison between 1850-1955 and 1965-2016 revealed a significant decrease of 23\% (Table 3). Significant correlations were detected between protein content and $\left[\mathrm{CO}_{2}\right]$ and temperature $(\mathrm{r}=-0.265$ and $\mathrm{r}=0.269$, respectively; Table 5). We also detected a significant effect of $\left[\mathrm{CO}_{2}\right]$ and temperature on protein content in the ANOVA, but no effect of the interaction effect (Table 6).

Mineral composition. At the global level, no significant difference was detected in C content during the period of study (Fig. 6A). However, given the decrease in protein content (that is tightly linked with the $\mathrm{N}$ content), the $\mathrm{C} / \mathrm{N}$ ratio showed a significant increase of 20\% between 1850-1955 and 1965-2016 (Fig. 7A, Table 3). A significant positive correlation was found between $\left[\mathrm{CO}_{2}\right]$ and $\mathrm{C} / \mathrm{N}$ ratio, as well as a significant effect of $\left[\mathrm{CO}_{2}\right]$ on this ratio in the ANOVA (Tables 5,6). On the contrary, a significant negative correlation was found between the temperature and the $\mathrm{C} / \mathrm{N}$ ratio (and a significant effect of the temperature in the ANOVA; Tables 5, 6).

The global analyses of macro/micro-elements showed that their concentrations tend to decrease as ambient $\left[\mathrm{CO}_{2}\right]$ increased (Fig. 8A). In fact, negative correlations were detected between all macro/micro-elements and $\left[\mathrm{CO}_{2}\right]$, and these correlations were significant (and the effect of $\left[\mathrm{CO}_{2}\right]$ significant in the ANOVA) for $\mathrm{K}, \mathrm{Mg}, \mathrm{Zn}$, $\mathrm{Fe}$ and $\mathrm{Mn}$ (Table 5). The magnitude of the reduction differed between minerals, and the most notable reductions were observed for Mn, Fe, $\mathrm{Zn}$ and $\mathrm{Mg}$ (Fig. 8A; Table 6). Temperature has also significantly affected $\mathrm{Mg}, \mathrm{Fe}$ and Mn concentrations, but no interaction with $\left[\mathrm{CO}_{2}\right]$ was detected (except for $\mathrm{Cu}$; Table 6). 


\begin{tabular}{|l|l|l|l|l|l|l|}
\hline Parameters & Yield & Starch & Sucrose & Glucose & Fructose & Protein \\
\hline Precipitation & $0.662^{\star * *}$ & -0.198 & 0.207 & 0.126 & -0.310 & 0.004 \\
\hline TKW & 0.193 & - & - & - & - & - \\
\hline
\end{tabular}

Table 4. Pearson correlation analyses (r) between environmental parameter (precipitation), and grain yield and quality traits of the Rothamsted Broadbalk experiment. A statistically significant effect is indicated with ${ }^{* * *}$ for $p<0.001$. '-' indicates unavailable coefficient of correlation (r).

\begin{tabular}{|c|c|c|c|c|}
\hline \multirow[b]{2}{*}{ Grain quality traits } & \multicolumn{2}{|l|}{ Global } & \multicolumn{2}{|c|}{ Rothamsted } \\
\hline & {$\left[\mathrm{CO}_{2}\right]$} & Temperature & {$\left[\mathrm{CO}_{2}\right]$} & Temperature \\
\hline Yield & - & - & $0.631^{* *}$ & $0.688^{* * *}$ \\
\hline$\Delta^{13} \mathrm{C}$ & 0.048 & 0.003 & $-0.688^{* * *}$ & 0.143 \\
\hline Starch & $0.247^{\star}$ & -0.175 & $0.458^{*}$ & $0.435^{\star}$ \\
\hline Glucose & $0.379^{* *}$ & $0.238^{*}$ & $0.591^{\star *}$ & $0.755^{* * *}$ \\
\hline Sucrose & $0.676^{* * *}$ & -0.03 & 0.209 & -0.424 \\
\hline Fructose & 0.131 & $0.257^{\star}$ & -0.224 & 0.293 \\
\hline Protein content & $-0.265^{\star *}$ & $0.269^{\star * *}$ & $-0.771^{\star * *}$ & $-0.474^{\star}$ \\
\hline $\mathrm{C} / \mathrm{N}$ ratio & $0.229^{* *}$ & $-0.396^{\star * *}$ & $0.691^{* * *}$ & $0.614^{\star *}$ \\
\hline $\mathrm{C}$ & -0.120 & 0.107 & $0.482^{\star}$ & 0.315 \\
\hline $\mathrm{K}$ & $-0.452^{\star * *}$ & -0.151 & $0.486^{\star}$ & $0.425^{\star}$ \\
\hline $\mathrm{P}$ & -0.124 & 0.036 & $-0.860^{* * *}$ & $-0.514^{*}$ \\
\hline $\mathrm{Ca}$ & -0.037 & $0.202^{*}$ & -0.391 & $-0.626^{* *}$ \\
\hline $\mathrm{Mg}$ & $-0.560^{\star * *}$ & 0.169 & $-0.852^{* * *}$ & $-0.698^{\star * *}$ \\
\hline $\mathrm{Cu}$ & -0.165 & -0.116 & $-0.437^{\star}$ & -0.370 \\
\hline $\mathrm{Na}$ & 0.054 & 0.080 & -0.324 & $-0.557^{\star *}$ \\
\hline $\mathrm{Zn}$ & $-0.285^{\star}$ & 0.097 & $-0.717^{* * *}$ & -0.346 \\
\hline $\mathrm{Fe}$ & $-0.188^{\star}$ & $0.212^{*}$ & -0.314 & -0.300 \\
\hline $\mathrm{Mn}$ & $-0.348^{\star * *}$ & $0.364^{* * *}$ & $-0.942^{* * *}$ & $-0.444^{\star}$ \\
\hline
\end{tabular}

Table 5. Pearson correlation analyses ( $\mathrm{r}$ ) between grain yield and quality traits, and environmental factors $\left(\left[\mathrm{CO}_{2}\right]\right.$ and temperature). Statistically significant effects are indicated with ${ }^{\star *}$ for $p<0.001,{ }^{* *}$ for $p<0.01$ and ${ }^{*}$ for $p<0.05$. ' - ' indicates unavailable coefficient of correlation (r).

Broadbalk Wheat experiment (Rothamsted, UK). Environmental conditions. Since the beginning of the Broadbalk wheat experiment in Rothamsted, the $\left[\mathrm{CO}_{2}\right]$ concentration increased by $45 \mathrm{ppm}$ from 1850 to 1975 (i.e., in 125 years), and by as much as $47 \mathrm{ppm}$ from 1975 to 2016 (i.e., in 41 years; Table 2). Annual temperatures were recorded from 1878 to 2016 . Available data showed that, while mean temperature during 1878 was of $9.3^{\circ} \mathrm{C}$, during, 2016, this value reached $10.3^{\circ} \mathrm{C}$. Precipitation data recorded between 1878 and 2016 in Rothamsted did not show a clear pattern over time and rather revealed random fluctuations among years (Table 2).

Grain yield and thousand kernel weight (TKW). The results provided by the Broadbalk experiment about grain yield and thousand kernel weight (TKW) are presented in Fig. 1. Grain yield was more or less constant from 1850 until 1960, but has been subsequently increasing. Correlation analyses revealed significant positive correlations between grain yield and precipitation, $\left[\mathrm{CO}_{2}\right]$ and temperature (Tables 4,5 ). Highly significant effects of $\left[\mathrm{CO}_{2}\right]$ and temperature on wheat yield were also observed (Table 6). Further, available data showed that TKW has been decreasing since 1974 (Fig. 1). Pearson analysis revealed non-significant correlation between TKW and grain yield (Table 4), and the multifactor ANOVA showed highly significant effects of $\left[\mathrm{CO}_{2}\right]$ and temperature on TKW (Table 6).

Carbon isotope discrimination $\left(\Delta^{13} \mathrm{C}\right)$. We observed a clear decrease of $\Delta^{13} \mathrm{C}$ during the last decades (Fig. 2B). The $\left[\mathrm{CO}_{2}\right]$ concentration was highly significantly and negatively correlated with $\Delta^{13} \mathrm{C}$ (Table 5), and had a significant effect on this variable (Table 6). The temperature has also significantly affected $\Delta^{13} \mathrm{C}$, but there was no significant effect of the $\left[\mathrm{CO}_{2}\right] \times$ temperature interaction.

Non-structural carbohydrates. Starch content. Grain starch content varied significantly among years since 1850 and reached the highest value in 2016 (Fig. 3B). It should also be noted that at Rothamsted, the increasing temperature might have contribute to favor starch accumulation $(p=0.034)$ by $43 \%$ (Table 5), but there was no correlation between precipitation and starch content (Table 4). Results presented in Table 4 showed insignificant 


\begin{tabular}{|c|c|c|c|c|c|c|}
\hline \multirow[b]{3}{*}{ Traits } & \multicolumn{3}{|l|}{ Global } & \multicolumn{3}{|c|}{ Rothamsted } \\
\hline & {$\left[\mathrm{CO}_{2}\right]$} & Temperature & {$\left[\mathrm{CO}_{2}\right] \times$ temperature } & {$\left[\mathrm{CO}_{2}\right]$} & Temperature & {$\left[\mathrm{CO}_{2}\right] \times$ temperature } \\
\hline & \multicolumn{3}{|l|}{$p$ value } & \multicolumn{3}{|l|}{$p$ value } \\
\hline Yield & - & - & - & $<0.001$ & 0.003 & 0.015 \\
\hline TKW & - & - & - & $<0.001$ & $<0.001$ & 0.164 \\
\hline$\Delta^{13} \mathrm{C}$ & 0.612 & 0.906 & 0.004 & $<0.001$ & $<0.001$ & 0.837 \\
\hline Starch & 0.009 & 0.008 & 0.525 & 0.026 & 0.247 & 0.700 \\
\hline Glucose & 0.001 & 0.079 & 0.249 & $<0.001$ & $<0.001$ & $<0.001$ \\
\hline Sucrose & $<0.001$ & 0.215 & 0.002 & 0.147 & $<0.001$ & 0.806 \\
\hline Fructose & 0.273 & 0.023 & 0.962 & 0.233 & 0.002 & 0.434 \\
\hline Protein content & $<0.001$ & $<0.001$ & 0.901 & $<0.001$ & 0.737 & 0.015 \\
\hline $\mathrm{C} / \mathrm{N}$ ratio & 0.001 & $<0.001$ & 0.064 & $<0.001$ & 0.060 & 0.794 \\
\hline $\mathrm{C}$ & 0.137 & 0.093 & 0.158 & 0.022 & 0.717 & 0.852 \\
\hline $\mathrm{K}$ & $<0.001$ & 0.446 & 0.001 & 0.016 & 0.296 & 0.318 \\
\hline $\mathrm{P}$ & 0.174 & 0.488 & 0.248 & $<0.001$ & 0.538 & 0.700 \\
\hline $\mathrm{Ca}$ & 0.682 & 0.018 & 0.552 & 0.035 & 0.010 & 0.857 \\
\hline $\mathrm{Mg}$ & $<0.001$ & $<0.001$ & 0.264 & $<0.001$ & 0.004 & 0.151 \\
\hline $\mathrm{Cu}$ & 0.065 & 0.345 & 0.027 & 0.038 & 0.416 & 0.849 \\
\hline $\mathrm{Na}$ & 0.559 & 0.444 & 0.755 & 0.084 & 0.019 & 0.218 \\
\hline $\mathrm{Zn}$ & 0.013 & 0.498 & 0.528 & $<0.001$ & 0.809 & 0.845 \\
\hline $\mathrm{Fe}$ & 0.035 & 0.047 & 0.273 & 0.141 & 0.448 & 0.340 \\
\hline $\mathrm{Mn}$ & $<0.001$ & $<0.001$ & 0.586 & $<0.001$ & 0.298 & 0.002 \\
\hline
\end{tabular}

Table 6. Multifactor analysis of variance (ANOVA). The calculation of $p$ values in based on multifactor analysis of variance ANOVA. Values in bold indicate significance $(p<0.05)$. ‘-’ indicates unavailable $p$ value.

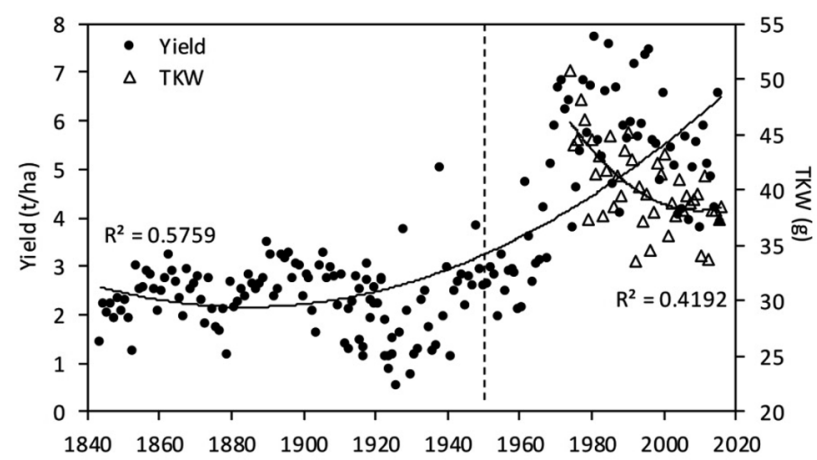

Figure 1. Trends in wheat yield and thousand kernel weight (TKW) of Broadbalk experiment from 1850 to 2016. Data are means. The dashed line represents the introduction of dwarf cultivars in 1968.

negative correlations between starch content and precipitations $(r=-0.198)$ whereas significant correlations have been recorded with $\left[\mathrm{CO}_{2}\right]$ and temperature (Table 5). According to the results presented in Table 6, only raising $\left[\mathrm{CO}_{2}\right]$ has a significant effect on grain starch content since 1850 to 2016 .

Soluble sugars concentrations. The concentrations of sucrose, glucose and fructose in wheat grains showed significant variations among years, as presented in Fig. 4B. Pearson analyses showed non-significant correlations between these concentrations and precipitation (Table 4). $\left[\mathrm{CO}_{2}\right]$ and temperature were significantly related to glucose concentration, as shown by both the positive correlations $(r=0.591$ and $r=0.755$, respectively; Table 5$)$ and the ANOVA (Table 6).

Protein content. Climate change has negatively impacted total protein content: A $26 \%$ reduction in protein content was recorded between 1850 and 2016 (Fig. 5B). Pearson analyses revealed that water availability was not correlated with protein content (Table 4 ), whereas temperature and (more significantly) $\left[\mathrm{CO}_{2}\right]$ were both negatively correlated with such content (Table 5). Based on the ANOVA, only $\left[\mathrm{CO}_{2}\right]$ but not temperature had a significant effect on protein content (Table 6). 

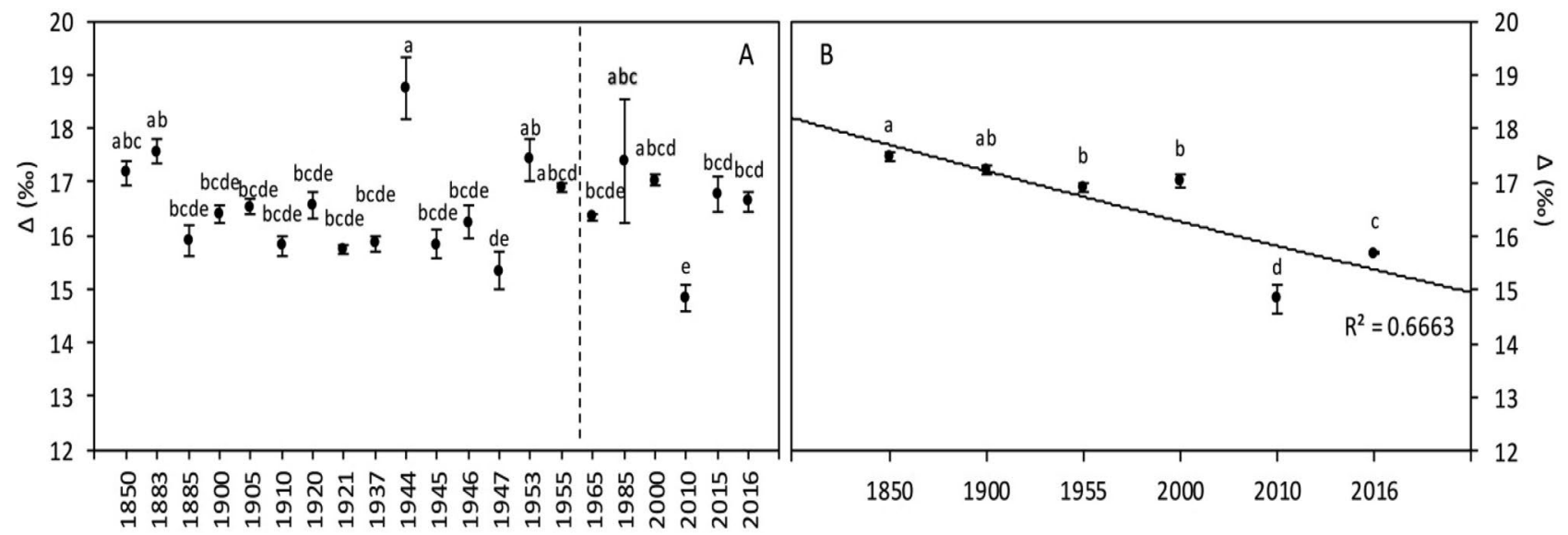

Figure 2. Wheat grain carbon isotope discrimination $\left(\Delta^{13} \mathrm{C}\right)$ of global $(\mathbf{A})$ and Broadbalk experiment $(\mathbf{B})$ samples. The dashed line corresponds to the separation between the [1850-1955] and [1965-2016] periods, based on the increase of $\left[\mathrm{CO}_{2}\right]$. Data are means \pm standard errors $(\mathrm{n}=3-14)$. The same letters indicate no statistically significant differences among years (Fisher's LSD, $p \geq 0.05$ ).

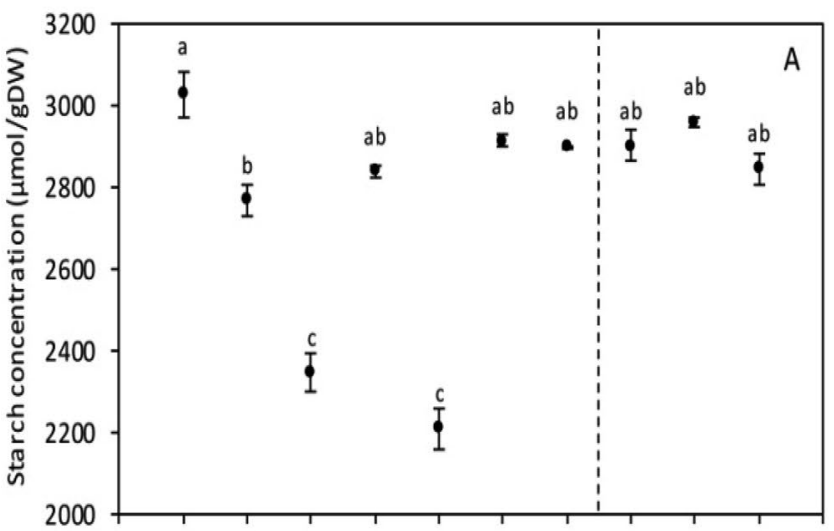

1850190019051920194619531955200020102016

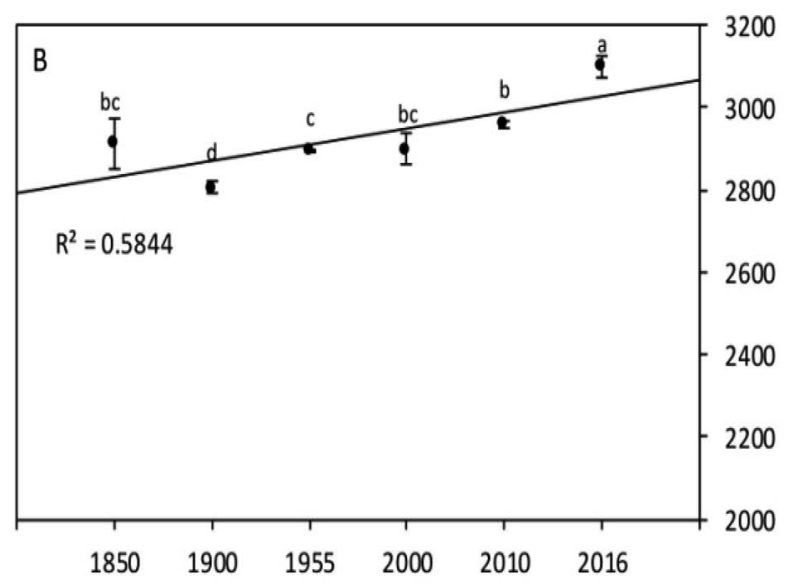

3200

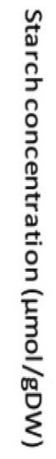

Figure 3. Wheat grain starch content of global (A) and Broadbalk experiment (B) samples. The dashed line corresponds to the separation between the [1850-1955] and [1965-2016] periods, based on the increase of $\left[\mathrm{CO}_{2}\right]$. Data are means \pm standard errors $(\mathrm{n}=3-14)$. The same letters indicate no statistically significant differences among years (Fisher's LSD, $p \geq 0.05$ ).

Mineral composition. Carbon content (Fig. 6B) showed a significant 3\% increase since 1850. Similarly, C/N ratio (Fig. $7 \mathrm{~B}$ ) showed a highly significant $40 \%$ increase, mainly caused by the significant decrease of protein content (and therefore $\mathrm{N}$ content) reported above. Only $\left[\mathrm{CO}_{2}\right]$, but not the temperature, was significantly correlated with and had a significant effect on $\mathrm{C}$ content (and consequently on $\mathrm{C} / \mathrm{N}$ ratio; Tables 5,6 ).

Macro/micro-elements concentrations have also been modified since 1850 (Fig. 8B). Statistical analyses showed that both $\left[\mathrm{CO}_{2}\right]$ and temperature (but most importantly $\left[\mathrm{CO}_{2}\right]$ ) had significant negative effects on mineral compositions (except for the $\mathrm{K}$ concentration that increased; Tables 5, 6).

\section{Discussion}

The current study, based on historical wheat samples collected over a 166-year period, has confirmed that grain quality and yield have been affected by raising atmospheric $\left[\mathrm{CO}_{2}\right]$ and temperature. The increase of $\left[\mathrm{CO}_{2}\right]$ and temperature, together with the introduction of dwarfing genotypes (see below), have increased harvest index, leading to rising wheat yield. Furthermore, carbon isotope discrimination has decreased over 166 years in the Broadbalk experiment (but not on worldwide samples collected across the same time period), which indicates that plants have been subjected to stressful conditions causing stomatal closure. With respect to grain quality parameters, our findings showed that non-structural carbohydrate concentrations have increased, while total protein content and mineral compositions have decreased.

The decreasing trend in TKW indicated that the increase in grain yield was not linked to heavier grains, but to a larger number of grains. While the effect of introducing semi-dwarf varieties should also be considered, our study showed that increasing $\left[\mathrm{CO}_{2}\right]$ favored crop production. Previous experiments, carried out with wheat plants grown in environments where atmospheric $\left[\mathrm{CO}_{2}\right]$ was increased by $150-300 \mathrm{ppm}$, showed similar increases 

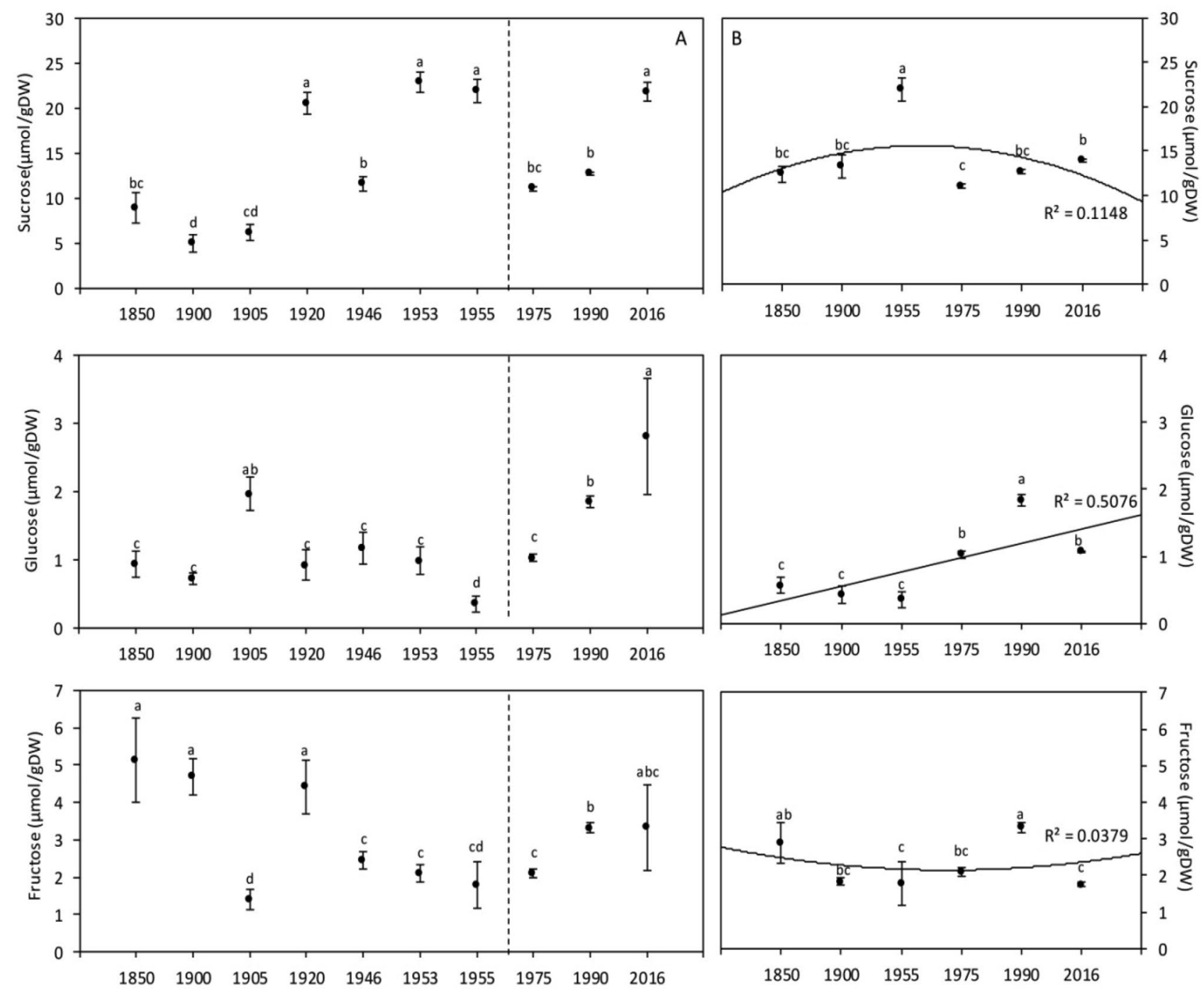

Figure 4. Wheat grain soluble sugar (sucrose, glucose and fructose) concentration of global (A,C,F) and Broadbalk experiment $(\mathbf{B}, \mathbf{D}, \mathbf{G})$ samples. The dashed line corresponds to the separation between the [1850$1955]$ and [1975-2016] periods, based on the increase of $\left[\mathrm{CO}_{2}\right]$. Data are means \pm standard errors $(\mathrm{n}=3-14)$.

The same letters indicate no statistically significant differences among years (Fisher's LSD, $p \geq 0.05$ ).
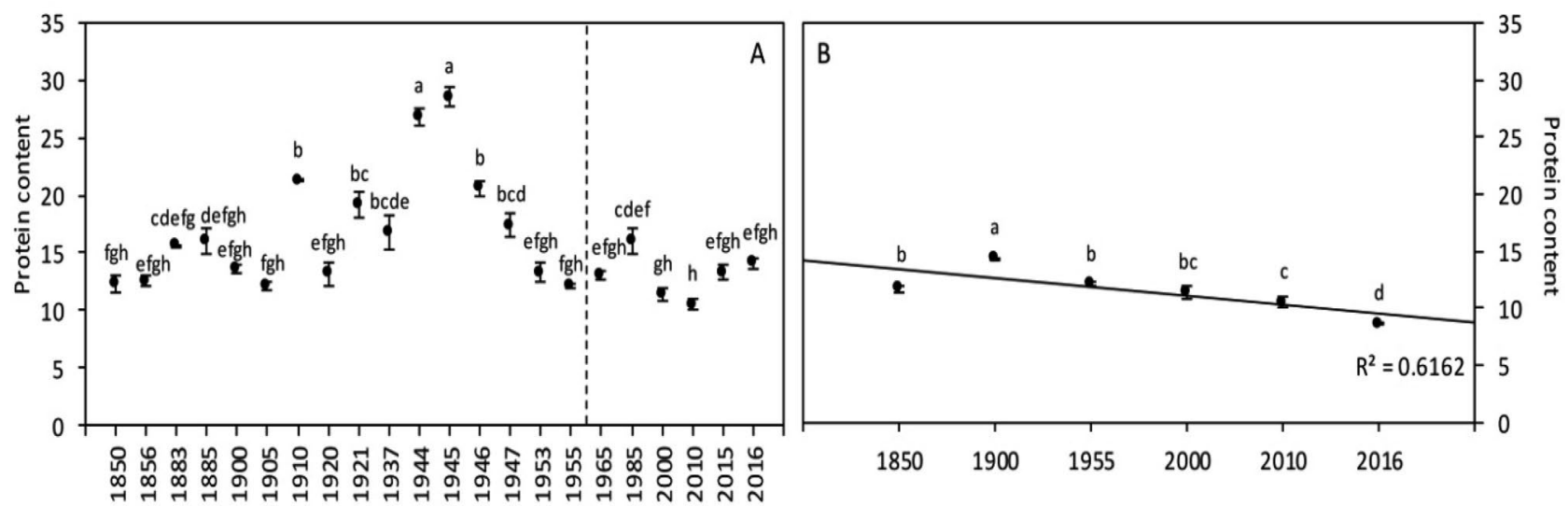

Figure 5. Wheat grain protein content of global (A) and Broadbalk experiment (B) samples. The dashed line corresponds to the separation between the [1850-1955] and [1965-2016] periods, based on the increase of $\left[\mathrm{CO}_{2}\right]$. Data are mean \pm standard errors $(\mathrm{n}=3-14)$. The same letters indicate no statistically significant differences among years (Fisher's LSD, $p \geq 0.05$ ). 


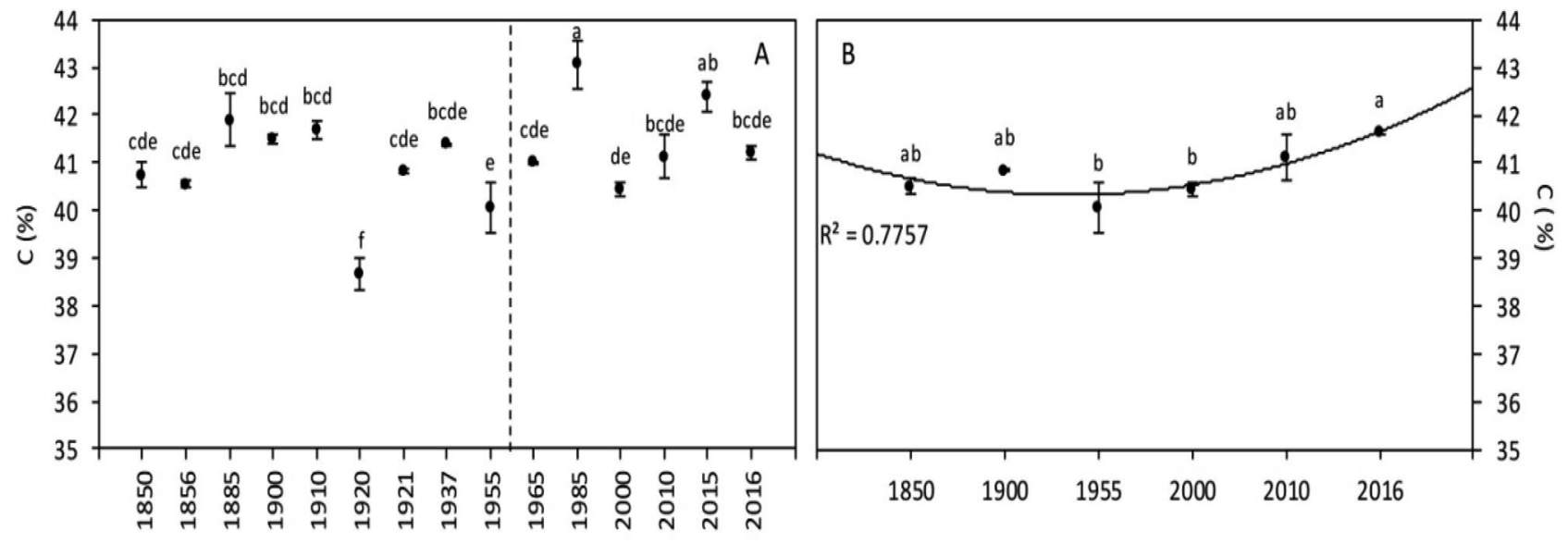

Figure 6. Wheat grain carbon content of global (A) and Broadbalk experiment (B) samples. The dashed line corresponds to the separation between the [1850-1955] and [1965-2016] periods, based on the increase of $\left[\mathrm{CO}_{2}\right]$. Data are means \pm standard errors $(n=3-14)$. The same letters indicate no statistically significant differences among years (Fisher's LSD, $p \geq 0.05$ ).
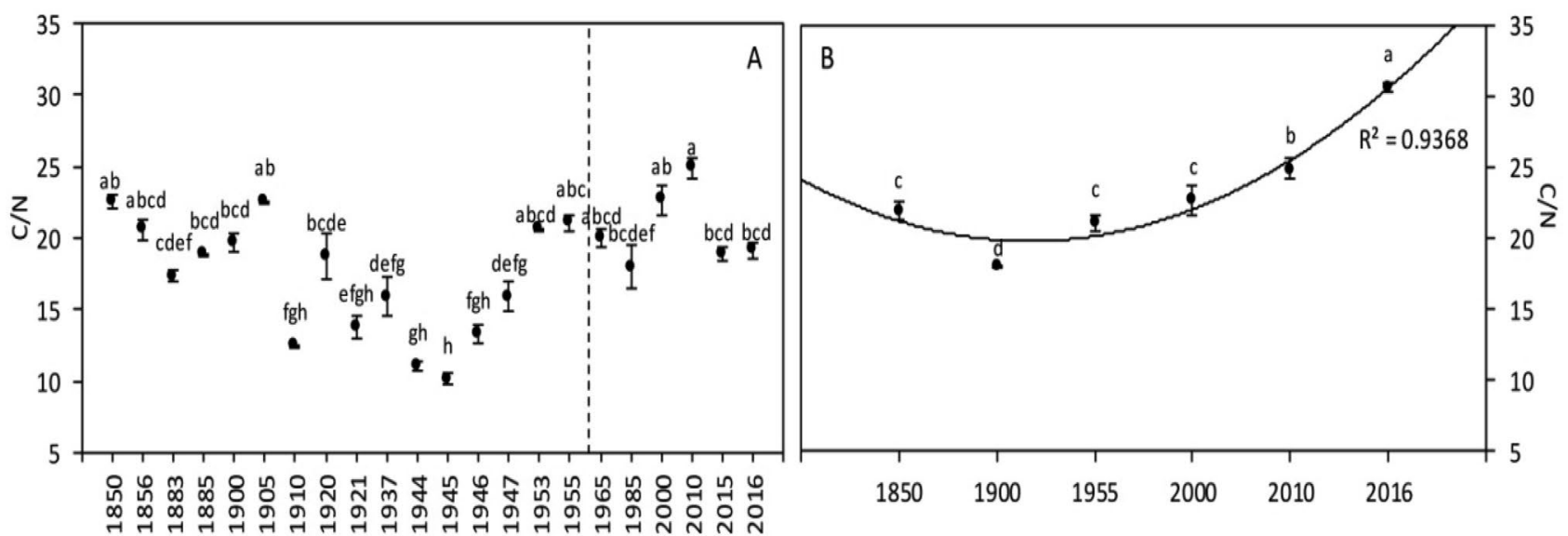

Figure 7. Wheat grain $\mathrm{C} / \mathrm{N}$ ratio of global (A) and Broadbalk experiment $(\mathbf{B})$ samples. The dashed line corresponds to the separation between the [1850-1955] and [1965-2016] periods, based on the increase of $\left[\mathrm{CO}_{2}\right]$. Data are means \pm standard errors $(n=3-14)$. The same letters indicate no statistically significant differences among years (Fisher's LSD, $p \geq 0.05$ ).

in grain yield values ${ }^{5,24}$. As has been widely described in these previous experiments, the higher yield records would be associated with the stimulation of photosynthetic rates. According to this study, alongside increasing radiation levels, the temperature rise was also an important factor explaining yield increases. More specifically, the enhancement of ambient temperatures (below heat stress values) might have contributed to extend the grain filling period, which subsequently resulted in a higher biomass production and a higher yield. Finally, when analyzing changes in crop yield during the last decades, together with increasing $\left[\mathrm{CO}_{2}\right]$ and temperature effects, changes in crop varieties could have an important effect. After 1968, high-yielding semi-dwarf cultivars (with increasing harvest index) were cultivated in the Rothamsted field trials and these cultivars have been reportedto distribute a greater proportion of photosynthates to the grains than other cultivars ${ }^{25}$.

The use of stable isotope variation has grown steadily in plant research during the past two decades. Stable isotopes are time-integrated indicators of how plants interact and respond to their abiotic and biotic environments ${ }^{26}$. Consequently, alterations in $\Delta^{13} \mathrm{C}$ have been used as a selection indicator of stomatal opening, water transpiration and water use efficiency (WUE) under different water availability and $\left[\mathrm{CO}_{2}\right]^{5,26}$. In the case of Rothamsted, the negative correlation between $\left[\mathrm{CO}_{2}\right]$ and $\Delta^{13} \mathrm{C}$ detected after the 1960 's revealed that following the increase in $\left[\mathrm{CO}_{2}\right]$ and temperature, and the decrease of precipitation, plants tended to decrease stomatal opening and reduce water loss via canopy transpiration ${ }^{19}$. As described by Aranjuelo et al. ${ }^{27}$, exposure to elevated $\left[\mathrm{CO}_{2}\right]$ might increase WUE by decreasing water consumption (due to a decline in stomatal opening and transpiration), by enhancing $\mathrm{CO}_{2}$ fixation, or by the interaction of both mechanisms. However, large genetic variation in carbon isotope discrimination exists among and between species. This variation could be widely explained by genotypic differences in stomatal conductance and photosynthetic capacity ${ }^{28}$. Hence, the absence of a temporal trend at 


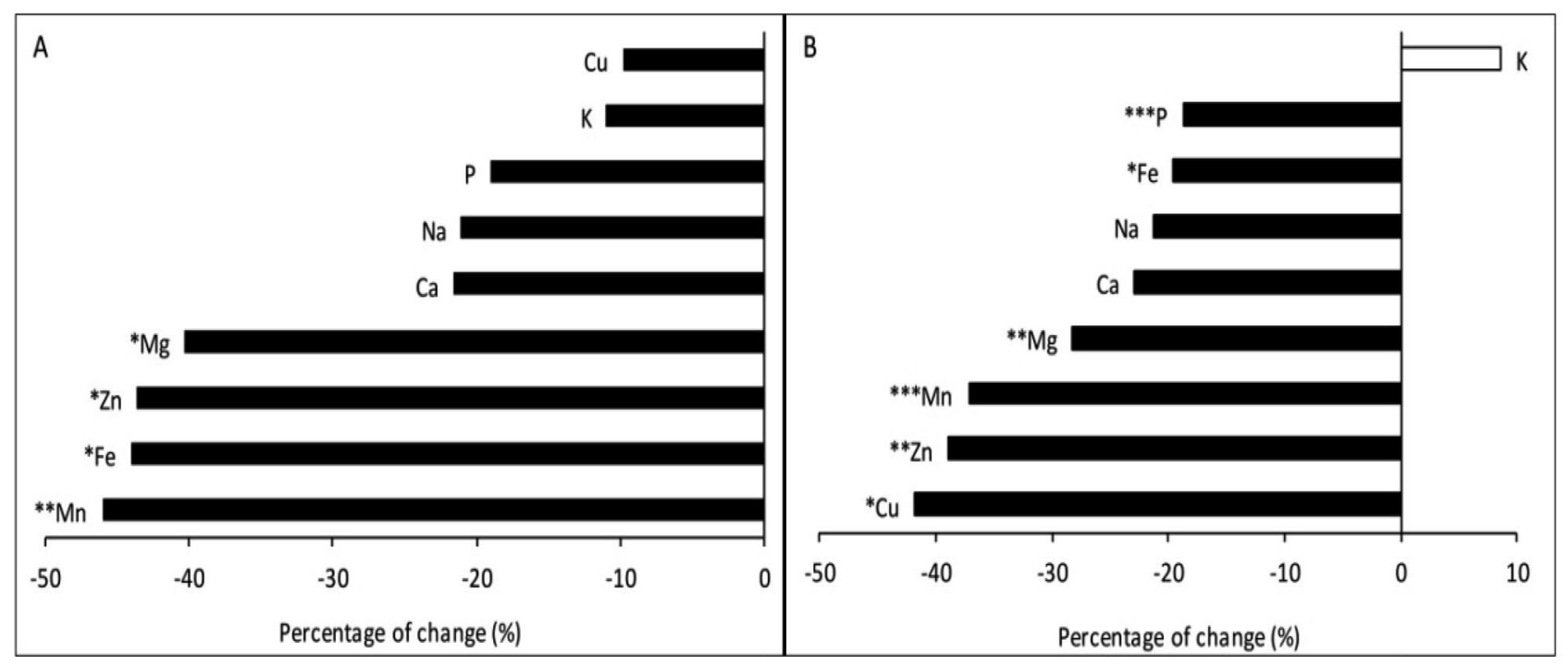

Figure 8. Change in grain minerals concentration relative to [1850-1955] period of global (A) and Broadbalk experiment $(\mathbf{B})$ samples. Data are means \pm standard errors $(n=3-14)$. Statistically significant effects are indicated with ${ }^{* *}$ for $p<0.001,{ }^{* *}$ for $p<0.01$ and ${ }^{\star}$ for $p<0.05$ (Fisher's LSD).

the global (worldwide) level, between 1850 and 2016, is probably mainly due to genotypic variability of cultivars grown at different locations.

About the carbohydrate content, studies conducted in controlled and FACE facilities showed that rising $\left[\mathrm{CO}_{2}\right]$ contributes to increases in starch and soluble sugar contents in wheat grains $\mathrm{s}^{29-31}$. The larger photosynthetic rates of $\mathrm{C}_{3}$ plants such as wheat under increasing $\left[\mathrm{CO}_{2}\right]$ may contribute to increased carbohydrate translocation from the source (leaves and stems) to the sink (grains), where the $\mathrm{C}$ is mainly stored in the form of starch. Furthermore, the positive correlation between yield and temperature at Rothamsted contributed to increased starch content. Considering that photosynthesis increases as leaf temperature rises (peaking at an optimum temperature and then declining), and that average temperature values in this area are below the optimum $\left(15-25^{\circ} \mathrm{C}\right)$, such an increase in ambient temperature might have contributed to increase photosynthesis and grain development ${ }^{32,33}$. Increases of ambient temperatures has been previously described and often results in an environmental temperature closer to the optimal, which results in increased photosynthesis ${ }^{34,35}$.

Alongside the increases in grain carbohydrates mentioned above, decreases in total protein and nutrient concentrations have been extensively described in plants exposed to elevated $\left[\mathrm{CO}_{2}\right]^{13,36}$. Different explanations have been proposed. According to some studies ${ }^{16,37}$, decreased protein and mineral concentrations could be a consequence of the larger carbohydrate content in grains. Our study showed a clear correlation between $\left[\mathrm{CO}_{2}\right]$ and $\mathrm{C} / \mathrm{N}$ ratio in all cases. Furthermore, we found that the starch concentration globally increased by $7 \%$ while grain protein content decreased by $23 \%$ between $1850-1955$ and 1965-2016. This may support the fact that grain protein decrease should also be associated with other mechanisms such as decreased transpiration-driven mass flow of nitrogen ${ }^{38,39}$. Furthermore, other factors such as the crop breeding approaches aimed at increasing crop yields (and declining response to $\mathrm{N}$ fertilizer) and limitations to $\mathrm{N}$ assimilation ${ }^{40}$ may have been involved. The positive correlation found between temperature and starch content in the Broadbalk experiment, as well as changes to the $\mathrm{C} / \mathrm{N}$ ratio, would also highlight how the temperature-associated increases in grain $\mathrm{C}$ content are involved in the lower grain protein contents observed.

The current study showed an overall decrease in all micro- and macronutrient concentrations in wheat grain over 166 years. Similarly, other historical studies have shown that mineral composition of the dry matter of wheat grains, vegetables and some fruits have decreased over time ${ }^{6,41-43}$. Such impoverishment may in part be associated with changes in atmospheric $\left[\mathrm{CO}_{2}\right]$ and temperature. The fact that the decreases were more evident in the Broadbalk experiment could be associated with different factors such as the strong increases in crop yield and lower ${ }^{13} \mathrm{C}$ discrimination $(\Delta)$ values detected in those plants during the recent decades. The potential impact of other factors such as alterations on nutrient uptake, and remobilization from leaves to grain and a greater transport of carbohydrates to grain (dilution) should also be considered. In addition, lower stomatal opening and a decrease of crop transpiration may have altered the mass flow of minerals from the soil to aboveground plant parts ${ }^{44,45}$. As observed by Fan et al. ${ }^{6}$, this explanation is especially likely since the concentrations of soil nutrients have not decreased at Rothamsted since the Green Revolution.

\section{Conclusions and perspectives}

Overall, this study highlighted that there has been a global trend of altered wheat grain quality characterized by an increase in non-structural carbohydrates and an impoverishment in total protein and mineral nutrients concentrations during the last 166 years. This trend has been especially prominent since the 1960 s and linked to the introduction of higher yielding short-strawed varieties, together with an increase in air $\left[\mathrm{CO}_{2}\right]$ and temperature. It seems likely that during this period enhanced photosynthetic rates linked to the increase in $\left[\mathrm{CO}_{2}\right]$ may have 
favored carbohydrate synthesis and carbon accumulation in grains and that this has negatively affected mineral composition. Along with a potential C-derived dilution effect, the current paper also implicates other factors such as depleted transpiration (affecting mineral transport) and the lower responsiveness of modern cultivars to current fertilization strategies. In view of the findings stated above, breeding strategies should develop new genotypes better adapted to changing environmental conditions with greater resource use efficiency and combine high grain nutritional values with high-yielding traits by exploring genetic variation in proteins and nutrients concentrations in wheat germplasm, since these traits are not only affected by environmental factors, but also are controlled genetically.

\section{Data availability}

The datasets analyzed during the current study are available from the corresponding author on reasonable request.

Received: 8 July 2020; Accepted: 20 November 2020

Published online: 11 December 2020

\section{References}

1. Scheelbeek, P. F. D. et al. Effect of environmental changes on vegetable and legume yields and nutritional quality. PNAS 115(26), 6804-6809. https://doi.org/10.1073/pnas.1800442115 (2018).

2. Intergovernmental Panel on Climate Change (IPCC). Climate change 2014: Synthesis report. In Contribution of Working Groups I, II and III to the Fifth Assessment Report of the Intergovernmental Panel on Climate Change (eds. Core Writing Team, Pachauri, R.K. \& Meyer, L.A.) (IPCC, Geneva, 2014). https://www.ipcc.ch/report/ar5/syr/.

3. European Environment Agency (EEA). (Accessed January 10, 2019) https://www.eea.europa.eu/.

4. Oury, F. X. et al. A study of genetic progress due to selection reveals a negative effect of climate change on bread wheat yield in France. Eur. J. Agron. 40, 28-38. https://doi.org/10.1016/j.eja.2012.02.007 (2012).

5. Erice, G. et al. Impact of elevated $\mathrm{CO}_{2}$ on yield and quality traits of a historical (Blanqueta) and a modern (Sula) durum wheat. J. Cereal Sci. 87, 194-201. https://doi.org/10.1016/j.jcs.2019.03.012 (2019).

6. Fan, M. S. et al. Evidence of decreasing mineral density in wheat grain over the last 160 years. J. Trace Elem. Med. Biol. 22, 315-324. https://doi.org/10.1016/j.jtemb.2008.07.002 (2008).

7. Nirgude, R. R. \& Sonawane, K. G. An estimation of impact of wheat production technology. Trends Biosci. 10(27), 5759-5766 (2017).

8. Degener, J. F. Atmospheric $\mathrm{CO}_{2}$ fertilization effects on biomass yields of 10 crops in northern Germany. Front. Environ. Sci. 3, 1-14. https://doi.org/10.3389/fenvs.2015.00048 (2015).

9. Kant, S. et al. Improving yield potential in crops under elevated $\mathrm{CO}_{2}$ : Integration the photosynthetic and nitrogen utilization efficiencies. Front. Plant Sci. 3, 1-9. https://doi.org/10.3389/flps.2012.00162 (2012).

10. DaMatta, F. M., Grandis, A., Arenque, B. C. \& Buckeridge, M. S. Impacts of climate changes on crop physiology and food quality. Food Res. Int. 43, 1814-1823. https://doi.org/10.1016/j.foodres.2009.11.001 (2010).

11. Taub, D. R., Miller, B. \& Allen, H. Effects of elevated $\mathrm{CO}_{2}$ on the protein concentration of food crops: A meta-analysis. Glob. Change Biol. 14(3), 565-575. https://doi.org/10.1111/j.1365-2486.2007.01511.x (2008).

12. Högy, P. \& Fangmeier, A. Effects of elevated atmospheric $\mathrm{CO}_{2}$ on grain quality of wheat. J. Cereal Sci. 48(3), 580-591. https://doi. org/10.1016/j.jcs.2008.01.006 (2008).

13. Loladze, I. Hidden shift of the ionome of plants exposed to elevated $\mathrm{CO}_{2}$ depletes minerals at the base of human nutrition. eLife 3, 1-29. https://doi.org/10.7554/eLife.02245 (2014).

14. Körner, C. Plant $\mathrm{CO}_{2}$ responses: An issue of definition, time and resource supply. New Phytol. 172, 393-411. https://doi.org/10.1 111/j.1469-8137.2006.01886.x (2006).

15. Morales, F. et al. Methodological advances: Using greenhouses to stimulate climate change scenarios. Plant Sci. 226, 30-40. https ://doi.org/10.1016/j.plantsci.2014.03.018 (2014).

16. Högy, P. et al. Effects of elevated $\mathrm{CO}_{2}$ on grain yield and quality of wheat: Results from a 3-year free-air $\mathrm{CO}_{2}$ enrichment experiment. Plant Biol. 11(Suppl1), 60-69. https://doi.org/10.1111/j.1438-8677.2009.00230.x (2009).

17. Pinkard, E. A., Beadle, C. L., Mendham, D. S., Carter, J. \& Glen, M. Determining photosynthetic responses of forest species to elevated $\left[\mathrm{CO}_{2}\right]$ : Alternatives to FACE. For. Ecol. Manag. 260, 1251-1261. https://doi.org/10.1016/j.foreco.2010.07.018 (2010).

18. Pinter, P. J. Jr. et al. Free air $\mathrm{CO}_{2}$ enrichment (FACE): Blower effects on wheat canopy microclimate and plant development. Agric. For. Meteorol. 103, 319-333. https://doi.org/10.1016/S0168-1923(00)00150-7 (2000).

19. Zhao, F. J., Spiro, B. \& McGrath, S. P. Trends in $C_{13} / C_{12}$ ratios and C isotope discrimination of wheat since 1875. Oecologia 128, 336-342. https://doi.org/10.1007/s004420100663 (2001).

20. Intergovernmental Panel on Climate Change (IPCC). Climate change 2007: Synthesis report. In Contribution of Working Groups I, II and III to the Fourth Assessment Report of the Intergovernmental Panel on Climate Change (eds. Core Writing Team, Pachauri, R.K. \& Reisinger, A.) (IPCC, Geneva, 2007). https://www.ipcc.ch/report/ar4/syr/.

21. Farquhar, G. D., Ehleringer, J. R. \& Hubick, K. T. Carbon isotope discrimination and photosynthesis. Annu. Rev. Plant Physiol. Plant Mol. Biol. 40, 503-537. https://doi.org/10.1146/annurev.pp.40.060189.002443 (1989).

22. Suchy, J. et al. Rapid assessment of glutenin and gliadin in wheat by UV spectrophotometer. Crop Sci. 47, 91-99. https://doi. org/10.2135/cropsci2006.05.0344 (2007).

23. Gámez, A. L. et al. Effect of water stress during grain filling on yield, quality and physiological traits of Illpa and Rainbow Quinoa (Chenopodium quinoa Willd.) cultivars. Plants 8, 173. https://doi.org/10.3390/plants8060173 (2019).

24. Högy, P., Zörb, C., Langenkämper, G., Betsche, T. \& Fangmeier, A. Atmospheric $\mathrm{CO}_{2}$ enrichment changes the wheat grain proteome. J. Cereal Sci. 50(2), 248-254. https://doi.org/10.1016/j.jcs.2009.06.002 (2009).

25. Flintham, J. E., Borner, A., Worland, A. J. \& Gale, M. D. Optimizing wheat grain yield: Effects of Rht (gibberellin-insensitive) dwarfing genes. J. Agric. Sci. 128, 11-25. https://doi.org/10.1017/S0021859696003942 (1997).

26. Yousfi, S., Serret, M. D. \& Araus, J. L. Comparative response of $\delta^{13} \mathrm{C}, \delta^{18} \mathrm{O}$ and $\delta^{15} \mathrm{~N}$ in durum wheat exposed to salinity at the vegetative and reproductive stages. Plant Cell Environ. 36, 1214-1227. https://doi.org/10.1111/pce.12055 (2013).

27. Aranjuelo, I., Irigoyen, J. J., Perez, P., Martinez-Carrasco, R. \& Sanchez-Díaz, M. The use of temperature gradient tunnels for studying the combined effect of $\mathrm{CO}_{2}$, temperature and water availability in $\mathrm{N}_{2}$ fixing alfalfa plants. Ann. Appl. Biol. 146, 51-60. https:// doi.org/10.1111/j.1744-7348.2005.04074.x (2005).

28. Dixon, L. S., Godoy, J. V. \& Carter, A. H. Evaluating the utility of carbon isotope discrimination for wheat breeding in the pacific northwest. Plant Phenomics https://doi.org/10.34133/2019/4528719 (2019). 
29. Sinha, P. G., Saradhi, P. P., Uprety, D. C. \& Bhatnagar, A. K. Effect of elevated $\mathrm{CO}_{2}$ concentration on photosynthesis and flowering in three wheat species belonging to different ploidies. Agric. Ecosyst. Environ. 142(3-4), 432-436. https://doi.org/10.1016/j. agee.2011.06.017 (2011).

30. Pandey, V. et al. Impact of elevated $\mathrm{CO}_{2}$ on wheat growth and yield under free air $\mathrm{CO}_{2}$ enrichment. J. Sci. Res. 6(4), 573-596. https ://doi.org/10.4236/ajcc.2017.64029 (2017).

31. Yadav, A., Bhatia, A., Yadav, S., Kumar, V. \& Singh, B. The effects of elevated $\mathrm{CO}_{2}$ and elevated $\mathrm{O}_{3}$ exposure on plant growth, yield and quality of grains of two wheat cultivars grown in north India. Heliyon 5(8), 1-11. https://doi.org/10.1016/j.heliyon.2019.e0231 7 (2019).

32. Nuttall, J. G. et al. Models of grain quality in wheat-A review. Field Crop Res. 202, 136-145. https://doi.org/10.1016/j. fcr.2015.12.011 (2017).

33. Posch, B. C. et al. Exploring high temperature responses of photosynthesis and respiration to improve heat tolerance in wheat. J. Exp. Bot. 70(19), 5051-5069. https://doi.org/10.1093/jxb/erz257 (2019).

34. Albert, K. R., Mikkelsen, T. N., Michelsen, A., Ro-Poulsen, H. \& Van der Linden, L. Interactive effects of drought, elevated $\mathrm{CO}_{2}$ and warming on photosynthetic capacity and photosystem performance in temperate heath plant. J. Plant Physiol. 168, 1550-1561. https://doi.org/10.1016/j.jplph.2011.02.011 (2011).

35. Sage, R. F. \& Kubien, D. S. The temperature response of $\mathrm{C}_{3}$ and $\mathrm{C}_{4}$ photosynthesis. Plant Cell Environ. 30, 1086-1106. https://doi. org/10.1111/j.1365-3040.2007.01682.x (2007).

36. Zhu, C. et al. Carbon dioxide $\left(\mathrm{CO}_{2}\right)$ levels this century will alter the protein, micronutrients, and vitamin content of rice grains with potential health consequences for the poorest rice-dependent countries. Sci. Adv. 4, 1-8. https://doi.org/10.1126/sciadv.aaq10 $12(2018)$.

37. Kimball, B. A. et al. Elevated $\mathrm{CO}_{2}$, drought and soil nitrogen effects on wheat grain quality. New Phytol. 150(2), 295-303. https:// doi.org/10.1046/j.1469-8137.2001.00107.x (2001).

38. Myers, S. S. et al. Increasing $\mathrm{CO}_{2}$ threatens human nutrition. Nature 510, 139-142. https://doi.org/10.1038/nature13179 (2014).

39. Uddling, J., Broberg, M. C., Feng, Z. \& Pleijel, H. Crop quality under rising atmospheric $\mathrm{CO}_{2}$. Plant Biol. 45, 262-267. https://doi. org/10.1016/j.pbi.2018.06.001 (2018).

40. Vicente, R. et al. Quantitative RT-PCR platform to measure transcript levels of C and N metabolism-related genes in durum wheat: Transcript profiles in elevated $\left[\mathrm{CO}_{2}\right]$ and high temperature at different levels of N supply. Plant Cell Physiol. 56, 1556-1573. https ://doi.org/10.1093/pcp/pcr079 (2015).

41. Garvin, D. F., Welch, R. M. \& Finley, J. W. Historical shifts in the seed mineral micronutrient concentration of US hard red winter wheat germplasm. J. Sci. Food Agric. 86, 2213-2220. https://doi.org/10.1002/jsfa.2601 (2006).

42. Morgounov, A. I. et al. Historical changes in grain yield and quality of spring wheat varieties cultivated in Siberia from 1900 to 2010. Can. J. Plant sci. 93, 425-433. https://doi.org/10.4141/CJPS2012-091 (2013).

43. White, P. J. \& Broadley, M. R. Biofortifying crops with essential mineral elements. Trend Plant Sci. 10, 586-593. https://doi. org/10.1016/j.tplants.2005.10.001 (2005).

44. Pilbeam, D. J. Breeding crops for improved mineral nutrition under climate change conditions. J. Exp. Bot. 66(12), 3511-3521. https://doi.org/10.1093/jxb/eru539 (2015).

45. Wang, Y. \& Frei, M. Stressed food-The impact of abiotic environmental stresses on crop quality. Agric. Ecosyst. Environ. 141(3-4), 271-286. https://doi.org/10.1016/j.agee.2011.03.017 (2011).

\section{Acknowledgements}

This work was supported by the Spanish Innovation and Universities Ministry (AGL2016-79868-R; PCIN2017-007), BBSRC Institute Strategic Programme grants, Designing Future Wheat (BB/P016855/1) and Soil to Nutrition (S2N, BBS/E/C/00I0310), the Long-term Experiments National Capability grant (BBS/E/C/000J0300), the Lawes Agricultural Trust and the Basque Country Government consolidated group programme (IT-932-16).

\section{Author contributions}

S.B.M.: Writing, performing lab and data analysis. A.L.G.: Statistical analysis. L.L.: Review. T.F.M.: Supervision and review. N.C.: Review. J.L.A.: Supervision and review. S.P.M.: Supervision and review. M.J.H.: Supervision and review. C.G.M.: Review. M.G.: Review. L.M.: Review. A.P.: Review. L.C.: Review. A.F: Supervision and review. J.B.: Supervision and review. S.T.P.: Supervision and review. A.J.M.: Supervision and review. I.A.: Supervision; editing and review. All authors read and approved the present manuscript.

\section{Competing interests}

The authors declare no competing interests.

\section{Additional information}

Supplementary information is available for this paper at https://doi.org/10.1038/s41598-020-78504-X.

Correspondence and requests for materials should be addressed to I.A.

Reprints and permissions information is available at www.nature.com/reprints.

Publisher's note Springer Nature remains neutral with regard to jurisdictional claims in published maps and institutional affiliations.

\footnotetext{
(c) (i) Open Access This article is licensed under a Creative Commons Attribution 4.0 International License, which permits use, sharing, adaptation, distribution and reproduction in any medium or format, as long as you give appropriate credit to the original author(s) and the source, provide a link to the Creative Commons licence, and indicate if changes were made. The images or other third party material in this article are included in the article's Creative Commons licence, unless indicated otherwise in a credit line to the material. If material is not included in the article's Creative Commons licence and your intended use is not permitted by statutory regulation or exceeds the permitted use, you will need to obtain permission directly from the copyright holder. To view a copy of this licence, visit http://creativecommons.org/licenses/by/4.0/.
}

(C) The Author(s) 2020 